\title{
Characteristics of Biochar Obtained by Hydrothermal Carbonization of Cellulose for Renewable Energy
}

\author{
Daegi Kim ${ }^{1}$, Kunio Yoshikawa ${ }^{2}$ and Ki Young Park ${ }^{1, *}$ \\ Received: 31 August 2015; Accepted: 8 December 2015; Published: 11 December 2015 \\ Academic Editor: Thomas E. Amidon \\ 1 Department of Civil and Environmental System Engineering, Konkuk University, 120 Neungdong-ro, \\ Gwangjin-gu, Seoul 143-701, Korea; daegi.kim81@gmail.com \\ 2 Department of Environmental Science and Technology, Tokyo Institute of Technology, 4259 Nagatsuta-cho, \\ Midori-ku, Yokohama 226-8503, Japan; yoshikawa.k.aa@m.titech.ac.jp \\ * Correspondence: kypark@konkuk.ac.kr; Tel./Fax: +82-2-447-3637
}

\begin{abstract}
The effect of hydrothermal carbonization on the properties of cellulose present in lignocellulosic biomass was investigated for converting it into a renewable energy resource with high energy recovery efficiency. The biochar obtained from cellulose subjected to hydrothermal carbonization showed a significant increase in its carbon content and a calorific value. ${ }^{13} \mathrm{C}$ NMR spectroscopy showed that when raw cellulose was subjected to hydrothermal carbonization above $220{ }^{\circ} \mathrm{C}$, the resulting biochar had more aromatic and aliphatic fractions than those in raw cellulose. The resulting composition of the biochars was comparable to that of solid fuels and was between that of lignite and sub-bituminous coal. Therefore, cellulose, the main component of lignocellulosic biomass, was used to investigate the effects of varying the reaction temperature during hydrothermal carbonization. The energy recovery efficiency calculations showed that the optimum reaction temperature for the transformation of a mixture of cellulose was approximately $220^{\circ} \mathrm{C}$.
\end{abstract}

Keywords: lignocellulosic biomass; cellulose; biochar; upgrading solid fuel; hydrothermal carbonization; energy recovery

\section{Introduction}

Biofuel obtained from lignocellulosic biomass, which is an abundant organic material, has an enormous potential as a feedstock for the production of renewable energy that can help in solving the current global energy issues, such as depletion of fossil fuel reserves and the need to reduce $\mathrm{CO}_{2}$ emissions that adversely affect the climate [1-3]. In recent years, the interest in lignocellulosic biomass has increased to make the upgraded biochar obtained from it a viable alternative to fossil fuels [3-5].

In order to obtain biofuels from lignocellulosic biomass, the major conversion technologies used are biological, chemical, and thermochemical conversion processes. The biological processes need a long treatment period and refinement systems [6,7]. On the contrary, the thermochemical treatment has several advantages, such as short processing times and high product yields with low risk of recovery efficiency $[8,9]$. Among the thermochemical methods, the hydrothermal treatment process for the conversion of biomass is being investigated mainly for producing liquid (bio-oil), solid (biochar), and/or gaseous (mainly carbon dioxide) fuels [10-15]. This process has generated widespread interest in recent years. Hydrothermal carbonization (HTC) comprises the use of a combination of a high temperature with high-pressure water (subcritical water) that made it the method with the highest potential among the various short-term methods available for using biomass as an energy source. 
Several reviews of the HTC process show that biomass with a low calorific value and high water content can be upgraded to a valuable carbon-rich-solid, lignite-like fuel [10-15]. The major chemical components of lignocellulosic biomass are cellulose, hemicellulose, and lignin. The hydrothermal conversion of each component of biomass influences the products to improve the overall quality of the end product, bringing it closer to the specification of a viable fuel. The most abundant component of biomass is cellulose, with a concentration of approximately $40 \%-70 \%$ [15-18]. Cellulose consists of linear polymer chains with highly crystalline structures that are insoluble in water and resistant to depolymerization [4,16-18]. The properties of cellulose after conversion by various treatments, including HTC, greatly influence the fuel properties of biochar obtained from lignocellulose.

The goal of this research is to improve the fuel properties of the cellulose of lignocellulosic biomass by disrupting the structure of this uniform compound by HTC reactions. For this purpose, various reactions that occur during the HTC of cellulose were investigated using pure cellulose extracted from lignocellulosic biomass. The chemical and structural characteristics of the hydrothermally-carbonized products that depend on the reaction temperatures were also investigated for applying lignocellulosic biomass as a viable energy source.

\section{Materials and Methods}

\subsection{Materials}

Pure cellulose ( $\alpha$-Cellulose-fiber, Nacalai Tesuque Inc., Kyoto, Japan) was tested to investigate the effects of hydrothermal conversion. The properties of pure cellulose are shown in Table 1.

Table 1. Properties of cellulose. d.b.: Dry basis.

\begin{tabular}{|c|c|c|c|c|c|c|c|c|c|}
\hline \multirow[b]{2}{*}{ Sample } & \multicolumn{3}{|c|}{ Proximate Analysis (wt. \%, d.b.) } & \multicolumn{4}{|c|}{ Ultimate Analysis (wt. \%, d.b.) } & \multirow[b]{2}{*}{$\begin{array}{l}\text { Calorific Value } \\
\text { (MJ/kg, d.b.) }\end{array}$} & \multirow{2}{*}{$\begin{array}{c}\text { Composition } \\
\text { of Biomass } \\
{[4,18]}\end{array}$} \\
\hline & $\begin{array}{l}\text { Volatile } \\
\text { Matter }\end{array}$ & $\begin{array}{c}\text { Fixed } \\
\text { Carbon }\end{array}$ & Ash & C & $\mathbf{H}$ & $\mathbf{N}$ & $\mathbf{O}$ & & \\
\hline Raw Cellulose & 93.4 & 6.1 & 0.5 & 43 & 6.4 & 0 & 50.1 & 16.5 & $40 \%-70 \%$ \\
\hline
\end{tabular}

\subsection{Hydrothermal Carbonization Process}

HTC experiments were performed using a 1 L lab-scale reactor (Hanwoul Eng. CO., LTD., Gunpo, Korea). The reactor consists of a body, a heater, and a steam condenser and is operated under a $\mathrm{N}_{2}$ atmosphere. During the experiments, $50 \mathrm{~g}$ of feedstock was supplied to the reactor with an equal amount of water. The operating temperatures and pressure ranged from 150 to $280{ }^{\circ} \mathrm{C}$ and 1.3 to $6.7 \mathrm{MPa}$, respectively, and the reaction time was $30 \mathrm{~min}$. The reaction components were mixed vigorously in the reactor using an agitator rotating at $200 \mathrm{rpm}$.

\subsection{Analytical Procedures}

The samples for the analysis were prepared in the powder form by sieving, and the fraction with particle sizes between 177 and $250 \mu \mathrm{m}\left(80-60\right.$ mesh) was separated after drying at $105^{\circ} \mathrm{C}$ for $24 \mathrm{~h}$. The elemental composition analysis of cellulose and its biochar was carried out using a PerkinElmer 2400 Series II CHN organic elemental analyzer (PerkinElmer, Waltham, MA, USA). Proximate analysis was conducted using a TGA-50 Thermogravicmetric analyzer (SHIMADZU, Tokyo, Japan). The calorific values were determined using a bomb calorimetric standard method according to JIS M-8814 [19]. The cross-polarization/magic angle spinning (CP/MAS) ${ }^{13} \mathrm{C}$ NMR spectra were measured on a solid state spectrophotometer (JEOL-ECA-600, JEOL, Peabody, MA, USA). The ${ }^{13} \mathrm{C}$ NMR (nuclear magnetic resonance) conditions were as follows: 1024 scans, spinning speed in excess of $8 \mathrm{kHz}$, contract time $1 \mathrm{~ms}$, and pulse repetition time $5 \mathrm{~s}$. Chemical shifts are in ppm and their changed structures were examined using a scanning electron microscope (SEM, S4500\&S4700, Hitachi, Japan) operating under vacuum. 


\subsection{Thermogravimetric Analysis}

The combustion characteristics of cellulose and the effect of HTC were determined by using a thermogravimetric analyzer (TGA). The thermogravimetric analysis was conducted by using a TGA-50 Thermogravicmetric analyzer. Non-isothermal combustion of all the samples was conducted in the furnace of the TGA system at atmospheric pressure. The sample weight loss and the weight loss rate were continuously recorded under the experimental conditions shown in Table 2. Each sample was tested three times, and the experiments showed a good reproducibility.

Table 2. Experimental conditions for the thermogravimetric analyzer (TGA).

\begin{tabular}{cc}
\hline \multicolumn{2}{c}{ TGA Conditions } \\
\hline Sample weight & $10 \mathrm{mg}$ \\
Heating rate & $10^{\circ} \mathrm{C} / \mathrm{min}$ \\
Atmosphere & Air \\
Gas flow rate & $150 \mathrm{~mL} / \mathrm{min}$ \\
Starting temperature & $45^{\circ} \mathrm{C}$ \\
Final holding temperature & $900^{\circ} \mathrm{C}$ \\
\hline
\end{tabular}

\section{Results and Discussion}

\subsection{Improvement of Cellulose Properties}

HTC changed the fuel properties of cellulose. Along with the results of the ultimate and proximate analyses, Table 3 also shows the change in cellulose properties at various HTC reaction temperatures. The fixed carbon content of cellulose increased from $6.1 \%$ to $35.0 \%$ in response to HTC at $220^{\circ} \mathrm{C}$ (Figure 1). This result suggests that the cellulose begins to decompose at $220^{\circ} \mathrm{C}$. As the fixed carbon content increased during HTC, the calorific value of cellulose increased from 16.5 to 18.9, 23.1, 26.5 and $27.7 \mathrm{MJ} / \mathrm{kg}$ at $180,200,220$ and $280^{\circ} \mathrm{C}$, respectively. These increased calorific values can be used to calculate the final effect of HTC over the quality of the biofuel (i.e., biochar) obtained from lignocellulosic biomass. This effect can most likely be attributed to the decomposition or pyrolysis of cellulose during HTC reactions to owing hydrolysis, chemical dehydration and decarboxylation reactions $[8-10,16]$.

Table 3. Effects of hydrothermal carbonization on changes in cellulose properties.

\begin{tabular}{|c|c|c|c|c|c|c|}
\hline Hydrothermal Carbonization at $\left({ }^{\circ} \mathrm{C}\right)$ & 150 & 180 & 200 & 220 & 250 & 280 \\
\hline \multicolumn{7}{|c|}{ Proximate Analysis (wt. \%, d.b. ${ }^{1}$ ) } \\
\hline Volatile matter & 88.9 & 89.3 & 84.0 & 63.6 & 56.9 & 42.2 \\
\hline Fixed carbon & 9.6 & 9.5 & 14.7 & 35.0 & 41.2 & 55.1 \\
\hline Ash & 1.5 & 1.2 & 1.3 & 1.4 & 1.9 & 2.7 \\
\hline \multicolumn{7}{|c|}{ Ultimate Analysis (wt. \%, d.b. ${ }^{1}$ ) } \\
\hline $\mathrm{C}$ & 43.9 & 45.6 & 51.2 & 63.5 & 69.4 & 76.5 \\
\hline $\mathrm{H}$ & 6.6 & 6 & 5.7 & 4.7 & 4.6 & 4.5 \\
\hline $\mathrm{N}$ & 0 & 0 & 0 & 0 & 0 & 0 \\
\hline $\mathrm{O}$ & 48 & 47.2 & 41.8 & 30.4 & 24.1 & 16.3 \\
\hline Calorific value (MJ / kg, d.b. ${ }^{1}$ ) & 16.6 & 18.9 & 23 & 26.5 & 26.8 & 27.7 \\
\hline \multicolumn{7}{|c|}{ Energy Recovery } \\
\hline Product yield $(\%)^{2}$ & 92.5 & 80.5 & 62.4 & 58.4 & 50.4 & 46.2 \\
\hline Energy recovery efficiency $(\%)^{3}$ & 93.0 & 92.4 & 87.1 & 93.8 & 81.9 & 77.7 \\
\hline Energy densification ${ }^{4}$ & 1.01 & 1.15 & 1.39 & 1.61 & 1.62 & 1.68 \\
\hline
\end{tabular}

The hydrolytic reactions caused by 1 mole of water cleave ester and ether bonds of the cellulose polymer leading to smaller molecules $[10,11,20,21]$. This hydrolysis reaction can lead to a complete conversion of the biomass within a few reaction cycles. Furthermore, the fuel properties of the 
main components of biomass (i.e., cellulose, hemicellulose and lignin) upgrade through chemical dehydration and decarboxylation reactions that release $\mathrm{H}_{2} \mathrm{O}$ and $\mathrm{CO}_{2}$ [10-13,21-23]. In addition to a loss in weight, these reactions decrease the volatile matter content and increase the carbon content of the biochar compared with that of the raw materials. These effects can be utilized for drying and carbonizing the biomass into an alternative fuel.

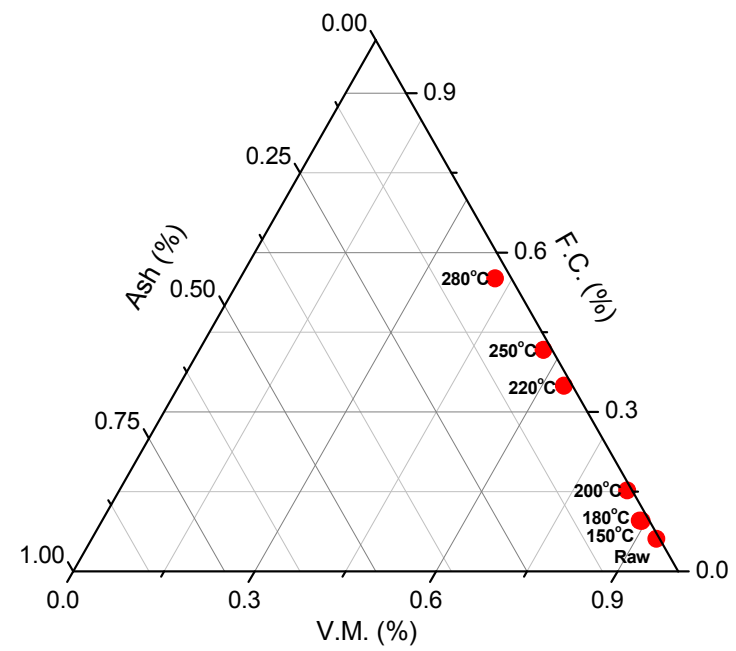

Figure 1. Change in cellulose properties caused by hydrothermal carbonization (F.C. is fixed carbon; V.M. is volatile matter).

\subsection{Coalification of Cellulose}

The HTC process can improve the properties of cellulose in a manner similar to the coalification process. The coalification bands of pure cellulose and its biochar were compared with the coalification band of various types of coal by using the van Krevelen diagram (Figure 2). Cellulose is known to have high $\mathrm{H} / \mathrm{C}$ and $\mathrm{O} / \mathrm{C}$ ratios, similar to other biomass materials [10-12,23-25]. The $\mathrm{H} / \mathrm{C}$ and $\mathrm{O} / \mathrm{C}$ ratios of cellulose decreased with the coalification status between lignite and sub-bituminous coal. This occurred when the cellulose was converted into carbonaceous products by chemical dehydration reactions during HTC $\left(4\left(\mathrm{C}_{6} \mathrm{H}_{10} \mathrm{O}_{5}\right)_{n} \rightarrow 2\left(\mathrm{C}_{12} \mathrm{H}_{10} \mathrm{O}_{5}\right)_{n}+10 \mathrm{H}_{2} \mathrm{O}\right)$ [10,18,20-22]. Consequently, HTC reactions can enhance biochar from the biomass by reducing the hydrogen and oxygen contents of the reaction products, resulting in an increased a calorific value of the biochar obtained from cellulose.

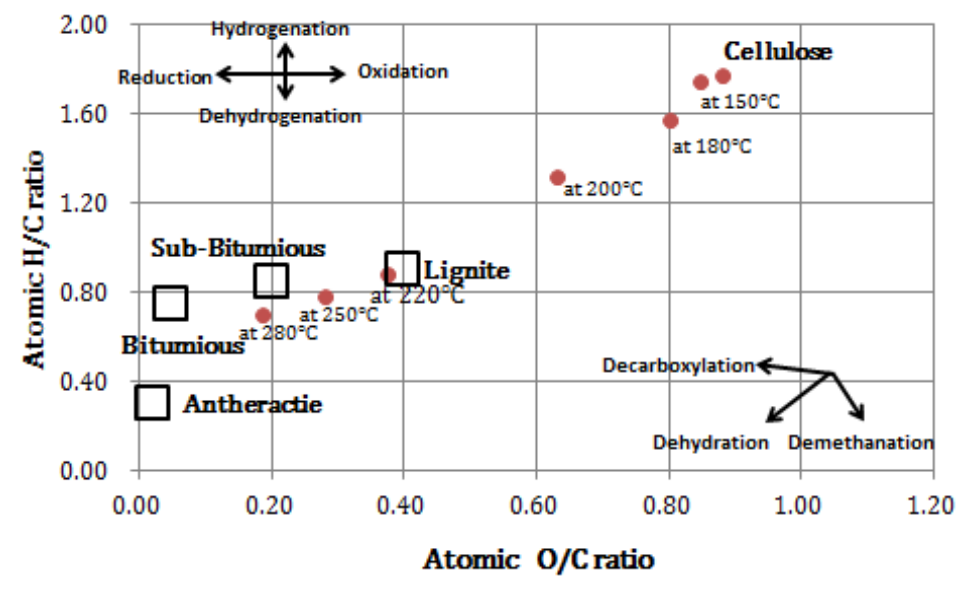

Figure 2. van Krevelen diagram of cellulose and its hydrothermally-obtained biochar based on the effect of the reaction temperature. 


\subsection{Changed Functional Groups of Cellulose and Related Compounds}

The atomicity of the carbon structures increased with increasing the HTC temperature, as shown in the ${ }^{13} \mathrm{C}$ nuclear magnetic resonance $\left({ }^{13} \mathrm{C}\right.$ NMR) measurements in Figure 3. The chemical shift ranges are grouped into four major regions, depending on the various functional groups: (i) a carboxyl region (160-200 ppm), (ii) an aromatic region (110-160 ppm), (iii) a carbohydrate region (59-110 ppm), and (iv) an aliphatic carbon region (0-59 ppm). The cellulose spectra peaks are assigned as follows: aliphatic carbon atom C-6, 62-65 ppm; C-2, C-3 and C-5 of cellulose, 70-77 ppm; C-4 of cellulose, 84 ppm; C-1 of cellulose, 105 ppm in carbohydrate regions; aromatic carbons, 110-127 ppm; a quaternary olefin or aromatic carbon, 127-143 ppm (oxygenated) that are non-oxygenated aromatic carbon region; olefinic and aromatic carbons (oxygenated) with $\mathrm{O}-\mathrm{H}$ or O-R substituent, 140-160 ppm in the aromatic region; carboxylic acid carbon atoms, 169-195 ppm [25-30].
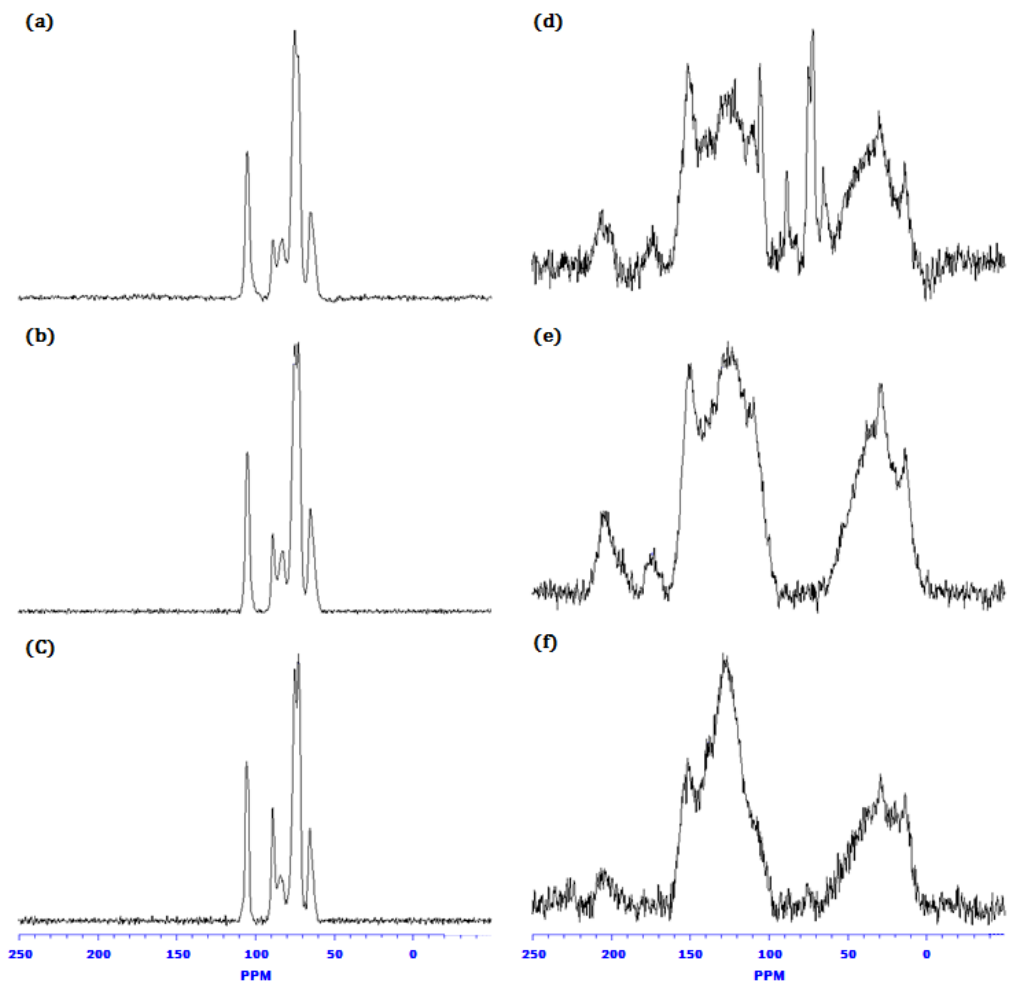

Figure $3 .{ }^{13} \mathrm{C}$ NMR spectra of cellulose (a) and their hydrothermal carbonization (HTC) biochar (b-f); (a) raw cellulose, (b) $180{ }^{\circ} \mathrm{C}$, (c) $200^{\circ} \mathrm{C}$, (d) $220^{\circ} \mathrm{C}$, (e) $250^{\circ} \mathrm{C}$ and (f) $280{ }^{\circ} \mathrm{C}$.

After HTC treatment above $220{ }^{\circ} \mathrm{C}$, the signals at $120-150 \mathrm{ppm}$ were assigned to the oxygen-substituted $\left(-\mathrm{OCH}_{3}\right.$ and $\left.-\mathrm{OH}\right)$ aromatic carbons in biochar, and the signal at 173 ppm was assigned to the acetyl or carbonyl group. In conjunction with C-1, C-2, C-4, and C-5 of cellulose shifting toward the higher field, this explains the decomposition of cellulose above $220{ }^{\circ} \mathrm{C}$ during HTC. The carbohydrate region including atoms C-1, C-2, C-3, C-4, and C-5 of cellulose, shifted toward the higher field during the decarboxylation reaction $\left(\mathrm{R}-\mathrm{COOH} \rightarrow \mathrm{R}-\mathrm{H}+\mathrm{CO}_{2}\right)$. Moreover, the cellulose structure was destroyed by the humification reaction at higher reaction temperatures during HTC. The aromatic $(\mathrm{C}-\mathrm{C} / \mathrm{C}=\mathrm{C})$ and aliphatic $\left(\mathrm{CH}_{2}, \mathrm{CH}_{3}\right)$ carbon regions of biochar obtained from cellulose increased owing to HTC reactions. These results explain the degradation of the carbohydrates of cellulose in lignocellulosic biomass by HTC above $220^{\circ} \mathrm{C}$.

The ${ }^{13} \mathrm{C}$ NMR of biochar obtained from cellulose in lignocellulosic biomass was compared with the shape of the spectra of products containing higher amounts of aromatic and aliphatic carbon regions. The results showed that the peak structures of highly aromatic coals 
resemble [24,27-30], despite the fact that the aromatic and aliphatic carbon peaks of the products obtained from hydrothermal process are not high enough to compare with those of the high- and medium-rank coals.

\subsection{Energy Recovery Efficiency}

As the reaction temperature increases, the calorific value of biochars also increase but the biochar yield decreases because of a decrease in the volatile matter content due to chemical dehydration and decarboxylation reactions (i.e., removal of $\mathrm{CO}_{2}$ ) [10-12]. Therefore, in hydrothermal reactions, an optimum temperature should be maintained to maximize the energy recovery efficiency (ERE) $[8,23,31,32]$. The ERE is an important parameter for evaluating the effect of HTC on biochar for solid fuel production (Figure 4). The highest ERE of each material indicates the optimum reaction temperature for HTC treatment. Cellulose decomposition began at $220^{\circ} \mathrm{C}$, and the optimum reaction temperature for maximizing the ERE was $220^{\circ} \mathrm{C}(\mathrm{ERE}=93.8 \%)$. This result suggests that the optimum temperature of hydrothermal treatment to produce more energy-rich solid fuel is approximately $200-220^{\circ} \mathrm{C}$. Since cellulose is the most abundant compound in lignocellulosic biomass $[3,5,18,20]$, the calorific value of cellulose was improved and the product yield was increased by HTC $[16,18,31,32]$.

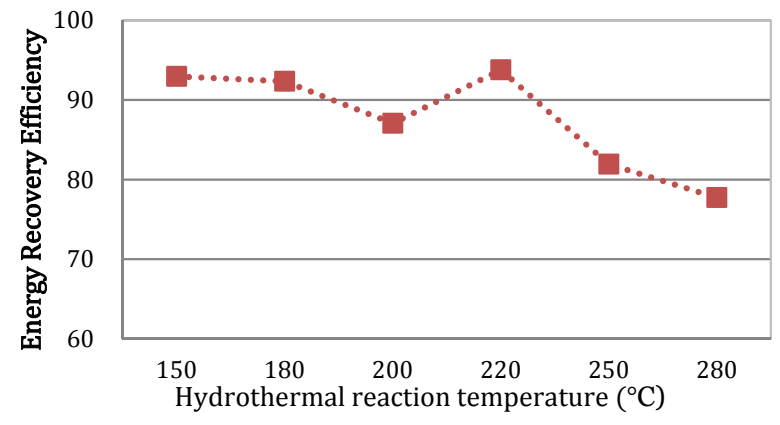

Figure 4. Energy recovery efficiency of cellulose and its biochar after HTC treatment.

\subsection{Combustion Behavior of Biochar}

Figures 5 and 6 show the TG (thermogravimetry) and DTG (derivative thermogravimetry) profile of cellulose and its hydrothermally obtained biochar. In the case of the products obtained below $220{ }^{\circ} \mathrm{C}$, the ignition temperature increased from 245 to $270{ }^{\circ} \mathrm{C}$, but the maximum burning temperature decreased from 380 to $290^{\circ} \mathrm{C}$. The increase in the fixed carbon content, increase in the surface area, and change in the pore structure of the biochar influence the ignition and maximum burning temperatures. As shown in Figure 6, HTC can lead to many micro-fissures in the biochar structures. Thus, the hydrothermally-obtained products became more easily combustible, with a reduced burn-out temperature.
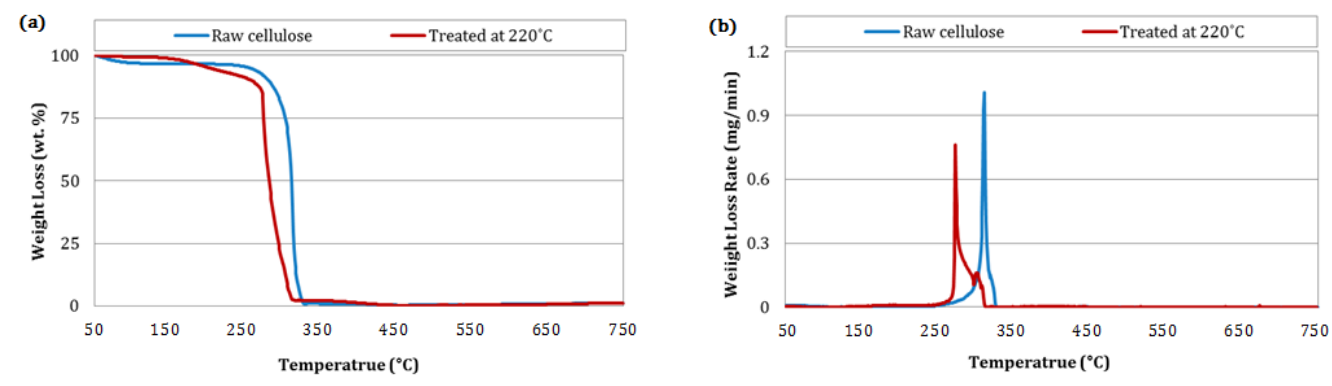

Figure 5. (a) TG and (b) DTG profiles of cellulose and its biochar at $220^{\circ} \mathrm{C}$. 

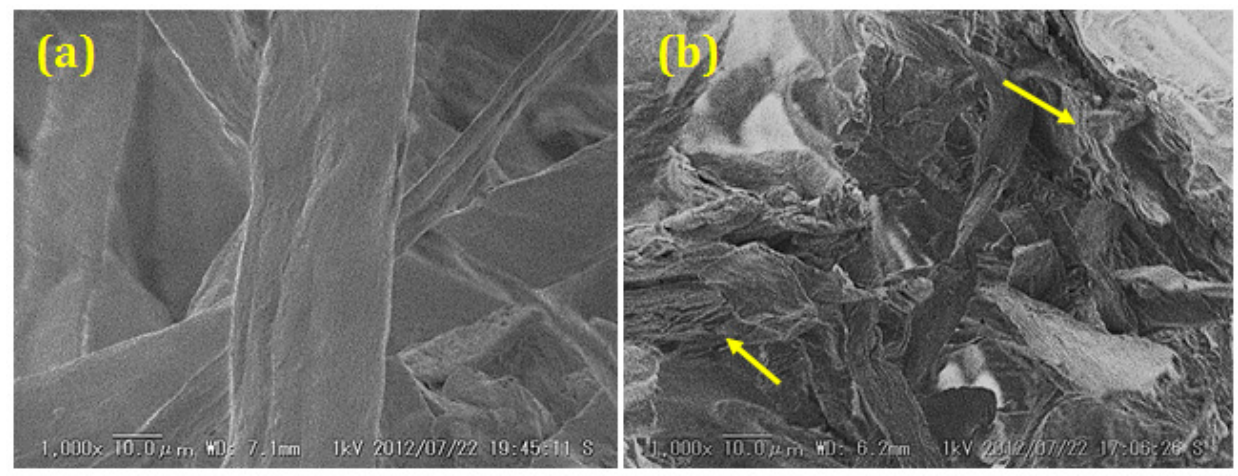

Figure 6. Scanning electron microscope (SEM) photography of cellulose and its biochar; (a) Raw cellulose; (b) HTC at $220^{\circ} \mathrm{C}$.

\section{Conclusions}

Biochar, technically manufactured by conducting the HTC of lignocellulosic biomass, has been proved to have high efficiency and it is also suitable as feedstock for bioenergy production. Cellulose, the predominant component of lignocellulosic biomass, is transformed to improve the characteristics of biochar obtained from biomass. The properties of biochar were greatly improved by HTC and were similar to those of coal-like fuel substances. The HTC process also increased the calorific values, fixed carbon value, and carbon contents. Moreover, HTC causes fissures in the structure of the solid residue, significantly altering its physical properties. Thus, the product is more easily combustible with a reduced burn-out temperature. These changes in the cellulose properties were very similar to those of the products obtained by coalification. Using ${ }^{13} \mathrm{C}$ NMR spectroscopy, we investigated how the initial structure of raw cellulose was changed owing to a progressive increase in the aromatic and aliphatic composition of the biochars. As a result, the biochars became similar to the solid fuel, with the characteristics corresponding to those of fuels between lignite and sub-bituminous coal. The optimum reaction temperature for a cellulose mixture was found to be approximately $220{ }^{\circ} \mathrm{C}$, as deduced from the ERE results. Thus, the results of this study indicate that HTC can be used as an effective means to generate highly energy-efficient renewable fuel resources.

Acknowledgments: This work is financially supported by Korea Ministry of Environment (MOE) as Waste to Energy and Recycling Human Resource Development Project and the Public Technology Program based on Environmental Policy Program (2014000710002) of the Korea Ministry of Environment.

Author Contributions: Daegi Kim, Kunio Yoshikawa and Ki Young Park conceived and designed the experiments; Daegi Kim performed the experiments; Daegi Kim, Kunio Yoshikawa and Ki Young Park analyzed the data; Daegi Kim contributed reagents/materials/analysis tools; Daegi Kim wrote the paper.

Conflicts of Interest: The authors declare no conflict of interest.

\section{References}

1. Reza, M.T.; Andert, J.; Wirth, B.; Busch, D.; Pielert, J.; Lynam, J.G.; Mumme, J. Hydrothermal carbonization of biomass for energy and crop production. Appl. Bioenergy 2014, 1. [CrossRef]

2. Hill, J.; Nelson, E.; Tilman, D.; Polasky, S.; Tiffany, D. Environmental, economic, and energetic costs and benefits of biodiesel and ethanol biofuels. Proc. Natl. Acad. Sci. USA 2006, 103, 11206-11210. [CrossRef] [PubMed]

3. Chandra, R.; Takeuchi, H.; Hasegawa, T. Hydrothermal pretreatment of rice straw biomass: A potential and promising method for enhanced methane production. Appl. Energy 2012, 94, 129-140. [CrossRef]

4. Mosier, N.; Wyman, C.; Dale, B.; Elander, R.; Lee, Y.Y.; Holtzapple, M.; Ladisch, M. Features of promising technologies for pretreatment of lignocellulosic biomass. Bioresour. Technol. 2005, 96, 673-686. [CrossRef] [PubMed] 
5. Liu, Z.; Quek, A.; Hoekman, S.K.; Balasubramanian, R. Production of solid biochar fuel from waste biomass by hydrothermal carbonization. Fuel 2013, 103, 943-949. [CrossRef]

6. Barrena, R.; d’Imporzano, G.; Ponsá, S.; Gea, T.; Artola, A.; Vázquez, F.; Sánchez, A.; Adani, F. In search of a reliable technique for the determination of the biological stability of the organic matter in the mechanical-biological treated waste. J. Hazard Mater. 2009, 162, 1065-1072. [CrossRef] [PubMed]

7. Yun, Y.S.; Park, J.I.; Park, J.M. High-rate slurry-phase decomposition of food wastes: Indirect performance estimation from dissolved oxygen. Process Biochem. 2005, 40, 1301-1306. [CrossRef]

8. Liu, Z.; Balasubramanian, R. Upgrading of waste biomass by hydrothermal carbonization (HTC) and low temperature pyrolysis (LTP): A comparative evaluation. Appl. Energy 2014, 114, 857-864. [CrossRef]

9. Yaman, S. Pyrolysis of biomass to produce fuels and chemical feedstocks. Energy Convers. Manag. 2004, 45, 651-671. [CrossRef]

10. Funke, A.; Ziegler, F. Hydrothermal carbonization of biomass: A summary and discussion of chemical mechanisms for process engineering. Biofuels Bioprod. Biorefin. 2010, 4, 160-177. [CrossRef]

11. Byrappa, K.; Adschiri, T. Hydrothermal technology for nanotechnology. Prog. Cryst. Growth Charact. Mater. 2007, 53, 117-166. [CrossRef]

12. Kim, D.; Lee, K.; Park, K.Y. Hydrothermal carbonization of anaerobically digested sludge for solid fuel production and energy recovery. Fuel 2014, 130, 120-125. [CrossRef]

13. Zhang, J.; Zhang, Y. Hydrothermal liquefaction of microalgae in an ethanol-water co-solvent to produce biocrude oil. Energy Fuels 2014, 28, 5178-5183. [CrossRef]

14. Manara, P.; Zabaniotou, A. Towards sewage sludge based biofuels via thermochemical conversion-A review. Renew. Sustain. Energy Rev. 2012, 16, 2566-2582. [CrossRef]

15. Libra, J.A.; Ro, K.S.; Kammann, C.; Funke, A.; Berge, N.D.; Neubauer, Y.; Titirici, M.M.; Fühner, C.; Bens, O.; Kern, J.; et al. Hydrothermal carbonization of biomass residuals: A comparative review of the chemistry, processes and applications of wet and dry pyrolysis. Biofuels 2011, 2, 71-106. [CrossRef]

16. Kim, D.; Prawisudha, P.; Yoshikawa, K. Hydrothermal upgrading of Korean MSW for solid fuel production: Effect of MSW composition. J. Combust. 2012, 2012. [CrossRef]

17. Jenkins, B.M.; Baxter, L.L.; Miles, T.R., Jr.; Mines, T.R. Combustion properties of biomass. Fuel Process. Technol. 1998, 54, 17-46. [CrossRef]

18. Garrote, G.; Dominguez, H.; Parajo, J.C. Hydrothermal processing of lignocellulosic materials. J. Wood Wood Prod. 1999, 57, 191-202. [CrossRef]

19. Japanese Industrial Standard (JIS M 8814). Coal and Coke Determination of Gross Calorific Value by the Bomb Calorimetric Method, and Calculation of Met Calorific Value; Japanese Industrial Standards Committee: Tokyo, Japan, 2003.

20. Sevilla, M.; Fuertes, A.B. The production of carbon materials by hydrothermal carbonization of cellulose. Carbon 2009, 47, 2281-2289. [CrossRef]

21. Quitain, A.T.; Faisal, M.; Kang, K.; Daimon, H.; Fujie, K. Low-molecular-weight carboxylic acids produced from hydrothermal treatment of organic wastes. J. Hazard. Mater. 2002, 93, 209-220. [CrossRef]

22. Hoekman, S.K.; Broch, A.; Robbins, C. Hydrothermal carbonization (HTC) of lignocellulosic biomass. Energy Fuels 2011, 25, 1802-1810. [CrossRef]

23. Berge, N.D.; Ro, K.S.; Mao, J.; Flora, J.R.V.; Chappell, M.A.; Bae, S. Hydrothermal carbonization of municipal waste streams. Environ. Sci. Technol. 2011, 45, 5696-5703. [CrossRef] [PubMed]

24. Tri Mursito, A.; Hirajima, T.; Sasaki, K. Upgraging and dewatering of raw tropical peat by hydrothermal treatment. Fuel 2010, 89, 635-641. [CrossRef]

25. Tri Mursito, A.; Hirajima, T.; Sasaki, K.; Kumagai, S. The effect of hydrothermal dewatering of Pontianak tropical peat on organics in wastewater and gaseous products. Fuel 2010, 89, 3394-3924. [CrossRef]

26. Xiao, L.P.; Shi, Z.J.; Xu, F.; Sun, R.C. Hydrothermal carbonization of lignocellulose biomass. Bioresour. Technol. 2012, 118, 619-623. [CrossRef] [PubMed]

27. He, W.; Li, G.; Kong, L.; Wang, H.; Huang, J.; Xu, J. Application of hydrothermal reaction in resource recovery of organic wastes. Resour. Conserv. Recycl. 2008, 52, 691-699. [CrossRef]

28. Freitas, J.C.; Bonagamba, T.J.; Emmerich, F.G. ${ }^{13} \mathrm{C}$ high-resolution solid-state NMR study of peat carbonization. Energy Fuels 1999, 13, 53-59. [CrossRef] 
29. Falco, C.; Perez Caballero, F.; Babonneau, F.; Gervais, C.; Laurent, G.; Titirici, M.M.; Baccile, N. Hydrothermal carbon from biomass: Structural differences between hydrothermal and pyrolyzed carbons via ${ }^{13} \mathrm{C}$ solid state NMR. Langmuir 2011, 27, 14460-14471. [CrossRef] [PubMed]

30. Cao, X.; Ro, K.S.; Chappell, M.; Li, Y.; Mao, J. Chemical structures of swine-manure chars produced under different carbonization conditions investigated by Advanced Solid-State ${ }^{13} \mathrm{C}$ Nuclear Magnetic Resonance (NMR) Spectroscopy. Energy Fuels 2010, 25, 388-397. [CrossRef]

31. Lu, X.; Pellechia, P.J.; Flora, J.R.; Berge, N.D. Influence of reaction time and temperature on product formation and characteristics associated with the hydrothermal carbonization of cellulose. Bioresour. Technol. 2013, 138, 180-190. [CrossRef] [PubMed]

32. Kang, S.; Li, X.; Fan, J.; Chang, J. Characterization of hydrochars produced by hydrothermal carbonization of lignin, cellulose, D-xylose, and wood meal. Ind. Eng. Chem. Res. 2012, 51, 9023-9031. [CrossRef]

(C) 2015 by the authors; licensee MDPI, Basel, Switzerland. This article is an open access article distributed under the terms and conditions of the Creative Commons by Attribution (CC-BY) license (http://creativecommons.org/licenses/by/4.0/). 